\title{
The Ontogenesis and Ontogenetic Structure of Lagochilus proskorjakovii Ikram (Lamiaceae) Coenopopulations in Nuratau Mountain Range (Uzbekistan)
}

\author{
A. K. Akhmedov ${ }^{*}$, H. F. Shomurodov ${ }^{2}$, Z. B. Nomozova ${ }^{1}$ \\ ${ }^{1}$ Department of Botany and Plant Physiology, Samarkand State University, Samarkand, Uzbekistan \\ ${ }^{2}$ Institute of the Gene Pool of Plants and Animals, Academy of Sciences Republic of Uzbekistan, Tashkent, \\ Uzbekistan \\ Email: "rakbar@rambler.ru
}

Received 4 March 2016; accepted 24 April 2016; published 27 April 2016

Copyright (C) 2016 by authors and Scientific Research Publishing Inc.

This work is licensed under the Creative Commons Attribution International License (CC BY).

http://creativecommons.org/licenses/by/4.0/

cc) (i) Open Access

\begin{abstract}
Lagochilus proskorjakovii Ikram is a strict endemic in Nuratau ridge (north-western spurs of the mountain range of the Pamir-Alai). It grows as a part of Amygdalus bucharica and Perovskia scrophulariifolia formation, where the total projective cover of grass does not exceed $20 \%$. In natural conditions growth, ontogeny of $L$. proskorjakovii is simple and complete. The duration of ontogenesis in the condition of Nuratau is no more than 22 - 23 years. Studied coenopopulations are normal, but are not complete. Coenopopulation self-maintenance is carried out by the seed of renewal. The characteristic spectrum of coenopopulation centered, with a peak in the middle-generative individuals. In most cases, specific developmental spectrum of coenopopulation coincides with the characteristic ones. The absence or small proportion of the young fraction in surveyed of coenopopulation is related to the elimination of young fragile individuals. According to the classification of "delta-omega", the most of coenopopulations are maturing which confirms the positive state of coenopopulation demography. Studied the ontogeny and structure of adult endemic Nuratau established that the species belongs to caudexum shrubs, perennial that forms the axis of the short multicipital caudex. Buds renewal is at a height of $2-3 \mathrm{~cm}$ above the substrate. Investigated coenopopulations $L$. proskorjakovii are successiveness conditions. In addition to the Artemisia juncea + Perovskia scrophulariifolia + Ferula ovina + Stipa hohenackeriana community $1^{\text {st }}$ coenopopulation (CP) mature; the $2^{\text {nd }} \mathrm{CP}$ is mature which was a part of the Amygdalus bucharica + Perovskia scrophulariifolia + Prangos pobularia + Bromus scoparius community; $3^{\text {rd }}$ CP is maturing being a part of Lonicera nummulariifolia + Perovskia scrophulariifolia + Hypericum scabrum + Bromus danthoniae community and the $4^{\text {th }} \mathrm{CP}$ is mature which occurred in Amygdalus bucharica +
\end{abstract}

\footnotetext{
${ }^{*}$ Corresponding author.
} 
Ferula varia + Acroptilon repens + Taeniatherum crinitum plant community.

Keywords

Demographic Characteristics, Ontogenetic Spectrum, Maturing, Mature, Plant Community, Coenopopulation Types

\section{Introduction}

Nuratau ridge includes a mountain Nuratau, Koytash, Gubdintau, Karachatau, Aktau and Karatau. This whole system of medium-arid lowlands and mountains, which are the extreme north-western of the mountain range of the Pamir-Alai and extending along a major tectonic line in Central Asia. There is given almost all the arid foothills and mountainous landscapes of Central Asia (except highlands), and most mountain of florocenotypes. This is the most western point spread microtherm juniper communites, which currently is virtually destroyed and preserved only in a few minor areas. The area is the westernmost outpost flora of Central Asian mountains [1]. In the north and north-west of Nuratau mountains contacted with the Kyzylkum desert to the east, they are in contact with Malguzar mountains, and through them with the Turkestan range. Nuratau ridge is one of the key botanical areas of Central Asia. There are not less than 1285 vascular plants of which 29 are strict endemics in Nuratau [2], one of which is L. proskorjakovii.

L. proskorjakovii is semi-shrubs 20 - $35 \mathrm{~cm}$ height. Root vertical, many-headed. Stems numerous, at the very bottom lignification, straight, simple or branched, strong, densely leafy, naked, on top of the small downy hairs papilliform at the bottom and covered later bares pale pink or white shiny crust. Leaves rhombic, base conical, 3 - 5 lobed or twin blades rounded or toothed plate 2.5 - $3.0 \mathrm{~mm}$ lower leaves. Petioles seated single with binomials lagging hairs; leaf blade on the lower side densely covered with glandular hairs. Flowers sessile 4 - 8 (10) in the axils of the upper leaves. Bracts strong, horizontal deflection, triangular, awl-shaped, wearing long spaced glands at the end of naked. Calyx 10 - 15 mm, campanulate, with widely rejected contour, more or less bent, with curved teeth, broadly, subulate-pointed upwards, to 1 - $1.5 \mathrm{~mm}$; calyx tube is covered with glandular hairs single. Corolla pale pink, 20 - $22 \mathrm{~mm}$, lower lip three-blade, top with shaggy light brown veins. Gynoecium exposed from corolla tube. Blooms in June-July, fruiting in August, [3], endemic of Pamir-Alai mountain [4].

Species of the genus Lagochilus have a potentially high economic value. The leaves and flowers of the plant are widely used as medicinal raw material. The leaves contain alcohols, lagochilin $(0.6 \%-2 \%)$, essential oils $(0.03 \%)$ and vitamin $\mathrm{K}$. The majority of the genus' members contain narcotic, hemostatic, and other substances [5]. Ineffective use of plant resources for human welfare has resulted in the loss of plant biodiversity worldwide. In parallel the number of endangered species has increased. The same developments have affected the flora of Uzbekistan, with the number of Red List plant species having almost doubled in the last 30 years: from 163 to 1984 to 324 at present. Species from the genus Lagochilus belong to the most vulnerable plant species from the Lamiaceae family. Out of existing 13 Lagochilus species in the flora of Uzbekistan, four are included in the Red Book of the Republic of Uzbekistan: Lagochilus vvedenskyi, L. olgae, L. Proskorjakovii and L. inebrians [6]. On the basis of occurrence, these Red List plant species belong to category I (disappearing) and II (rare species). In addition, the natural distribution of other species from this genus, such as Lagochilus gypsaceus and Lagochilus acutilobus are also limited across the country.

At present, populations of Lagochilus species are highly affected by the influence of various natural and anthropogenic factors and, as a result, strong reductions of the natural habitats of these species have been observed [7]-[9]. The reduction of the natural habitats of Lagochilus species dictates undertaking of detailed and in-depth ecological studies of these plants in order to develop better, science-based and practical measures for their conservation and restoration. The main purpose of the current work is to study the ontogenesis and ontogenetic structure L. proskorjakovii, identification of coenopopulation types and assessment their current state in natural conditions of Nuratau mountains.

\section{Materials and Methods}

Field surveys on studying of native populations of L. proskorjakovii was conducted in 4 coenopopulations in 
Nuratau mountains. For the first time L. proskorjakovii was found and described by Ikramov from Nuratau in 1964 [10]. The plant is strict endemic for Nuratau and distributed only in this region. For our studies, we have selected only 4 CPs due to the limited distribution of $L$. proskorjakovii in Nuratau. However, the selected CPs differ by its characteristic composition of plant community and their habitat. Research conducted during the vegetation period of 2008-2015 years in 4 selected coenopopulations of $L$. proskorjakovii (Figure 1). Descriptions of plant communities and coenopopulations' structure was done according to conventional geobotanical methods [11].

Detailed ontogenetic studies on L. proskorjakovii under natural conditions were not previously conducted. Studying the ontogeny was performed using conventional methods and approaches [12]-[14]. Describing the structure of the adult individuals of a species is based on the methods on dwarf semi-shrubs structure [15].

Structure of coenopopulations was studied by conventional methods [14] [16] [17]. In each coenopopulations 10 to 15 plots with $1 \mathrm{~m}^{2}$ were allocated. Ontogenetic structure of populations defined as the ratio of populations of individuals of different developmental states. For the unit of account is taken individual. Characterization the population structure based on the idea of the typical ontogenetic spectrum [18]. Coenopopulations are characterized by the classifications of and "delta-omega" of [19]. Density is defined as the number of plants in $1 \mathrm{~m}^{2}$ area [20], the names of vascular plants led by Czerepanov [21] (Figure 2).

\section{Results and Discussion}

Total projective cover of grass in coenopopulations is reached $10 \%-20 \%$, while the share of $L$. proskorjakovii does not exceed 1\% (Table 1). In natural conditions, L. proskorjakovii reproduces only by seed. Seeds germinate in the middle of February-early March. According to Ikramov [10] germination does not exceed 26\%.

Seedling $(\mathbf{P})$ L. proskorjakovii Ikram is one stem of plant with cotyledon and green leaves. During germination, hypocotyl makes cotyledons above the soil surface. Cotyledon leaves elliptical shape with the length of (accounting stem) $0.3-0.5 \mathrm{~cm}$. Axils cotyledons laid open buds. Opposite assimilating leaves are located on

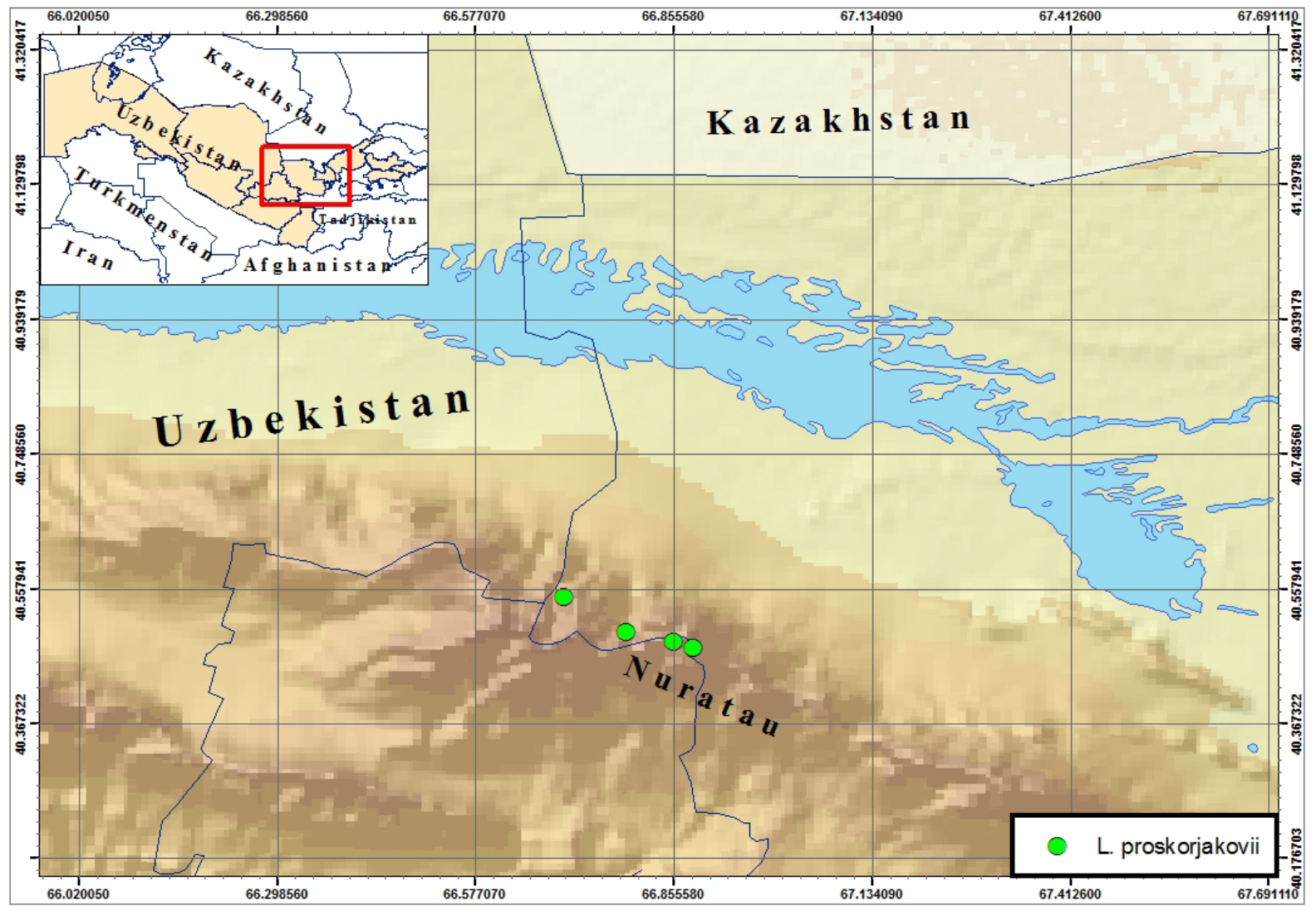

Figure 1. Green cycles on the map showing the location of study areas of L. proskorjakovii in Nuratau. 


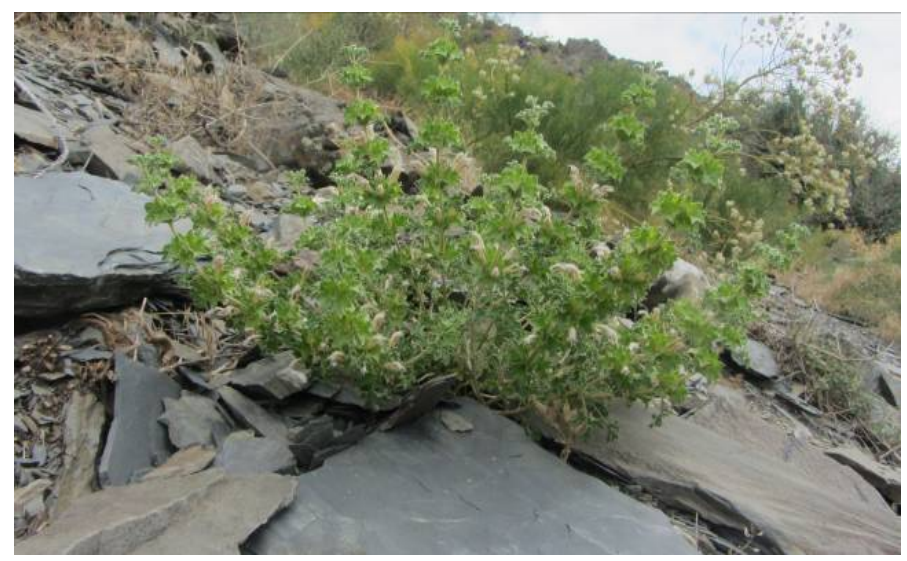

Figure 2. General view of L. proskorjakovii at the middle generative ontogenetic stage.

Table 1. Characteristics of the studied coenopopulation of L. proskorjakovii in Uzbekistan (Jizzakh region, Farish district, Nuratau ridge).

\begin{tabular}{|c|c|c|c|c|}
\hline No. CP & $\begin{array}{c}\text { Geographical coordinates/ } \\
\text { Elevation } / \mathrm{m}\end{array}$ & Community/dominant species & $\begin{array}{l}\text { Total projective cover } \\
\text { of vegetation, } \%\end{array}$ & $\begin{array}{l}\text { The projective cover } \\
\text { of this species,\% }\end{array}$ \\
\hline 1 & $\begin{array}{c}\mathrm{N} 40^{\circ} 30^{\prime} 644^{\prime \prime} \\
\text { E0 66 } 43 \text { '344" } \\
\text { Elevation }=1835 \mathrm{~m}\end{array}$ & $\begin{array}{c}\text { Artemisia juncea, Perovskia scrophulariifolia, } \\
\text { Stipa hohenackeriana, Oxytropis tachtemis } \\
\text { Poa relaxa, Tulipa turkestanica.. }\end{array}$ & $15-20$ & $\leq 1$ \\
\hline 2 & $\begin{array}{c}\mathrm{N} 40^{\circ} 50^{\prime} 085^{\prime \prime} \\
\mathrm{E} 066^{\circ} 98^{\prime} 346^{\prime \prime} \\
\text { Elevation }=1470 \mathrm{~m}\end{array}$ & $\begin{array}{c}\text { Amygdalus bucharica, Perovskia scrophulariifolia, } \\
\text { Artemisia juncea, Ferula ovina, Prangos pobularia, } \\
\text { Poa relaxa, Bromus scoparius. }\end{array}$ & $10-15$ & $\leq 1$ \\
\hline 3 & $\begin{array}{c}\mathrm{N} 40^{\circ} 44^{\prime} 075^{\prime \prime} \\
\text { E0 } 66^{\circ} 95^{\prime} 246^{\prime \prime} \\
\text { Elevation }=1523 \mathrm{~m}\end{array}$ & $\begin{array}{c}\text { Perovskia scrophulariifolia, Poa bulbosa, } \\
\text { Ferula ovina, Bromus danthoniae, } \\
\text { Hypericum scabrum }\end{array}$ & $10-12$ & $\leq 1$ \\
\hline 4 & $\begin{array}{c}\mathrm{N} 40^{\circ} 61^{\prime} 095^{\prime \prime} \\
\text { E0 66 } 99^{\prime} 443^{\prime \prime} \\
\text { Elevation }=1365 \mathrm{~m}\end{array}$ & Amygdalus bucharica, Ferula varia. & $8-10$ & $\leq 1$ \\
\hline
\end{tabular}

stalks. Leaf blade obovate, its length and width $0.2-0.3 \mathrm{~cm}, 0.3-0.5 \mathrm{~cm}$. Epicotyl length of $10-20 \mathrm{~mm}$. The main root reaches $2.0-3.0 \mathrm{~cm}$, branched and lasts a few weeks.

The juvenile (j) state of the plant goes into seed germination year after drying cotyledons. Juvenile one stems are monopodially growing plants. On the long shoots are formed of $5-7$ pairs of leaves on long stalks, their obovate plate $1.0-1.5 \mathrm{~cm}$ in length and width $0.4-0.6 \mathrm{~cm}$. The height of the main maternal length is $4.0-6.0$ $\mathrm{cm}$. The lateral buds are laid open in the axils of leaves. Some of them start to grow, forming shoots enrichment 1 - 3 elongated metameres. The main root reached $6.0-8.0 \mathrm{~cm}$ in length. By the end of the growing season, most of the stalks wither and die. Alive preserved bud sinus cotyledons.

The immature (im) status of individuals pass, usually for the next year. Renewal is due to one of the lateral buds cotyledons. Monopodial rise is replaced by sigmoidal. Spear resumption elongated monocyclic, and consists of 2 shortened and elongated 5 - 6 metameres. The nodes of the shoot diagonally oppositely arranged ternate lobed leaves on long stalks, with a distinct edge of the plate winding, leaf venation palmatiform. The width of the leaf blade and the length of petiole is $1.5-2.0 \mathrm{~cm}$ and $0.6-0.8 \mathrm{~cm}$, respectively. As in the juvenile state, the nodes are formed elongated metameres sylleptic shoots enrichment.

At the end of the growing season most of the shoot dries renewal, but does not die. Its basal part consisting of 2 short and 1 elongated metameres stored live bud. The basal part of the shoot, hypocotyl and main root thicken. The length of the main root is $12-15 \mathrm{~cm}$, branching to the II order.

On 3 year, individuals are moving in virginal $(\mathbf{V})$ ontogenetic state. Plants are branched by the buds in the nodes short metameres above lying elongated. Bush consists of 2 - 3 annual renewal of long shoots that can branch out; forming an elevated part sylleptic shoots enrichment. In the long shoot up to $4.0-10 \mathrm{~cm}$ deployed 9 
- 11 pairs of leaves. Leaf blades on shoots with well-defined segments including 3 - 5 on each separate shapeseparate leaves are trifoliate, veining during ontogeny does not change, it palmate-edge. Leaf length is 1.0 - 1.5 $\mathrm{cm}$ and $0.5-1.0 \mathrm{~cm}$ width. The main root is thickened, especially in the basal part of the branches to IV order. Its covering tissues are torn and partially exfoliated. Some parenchyma dies, resulting in visual isolation of conductive strands. The withering away of shoots, as in the previous condition, it occurs before the first elongate metameasure. They give rise to the basal portion 2, at least 3 skeletal axes. The duration is less than 2 years. Young generative (g1) individuals in the bush consist of 1 - 2 and 2 - 3 generative vegetative shoots. Due to the growth in the scree, renewal zone in this state is shifted to the elongated 2 - 3 metameres. The underlying buds are sleeping. Annual growth sympodial main axes consist of 2 short and elongated metameasure $2-3$. They are lignified and thickened. Generative shoot up to $10-12 \mathrm{~cm}$ monocyclic elongated. On orthotropic aerial part of generative shoots, develop 6 - 12 pair's ternately dissected leaves up to $1.5 \mathrm{~cm}$ in length and width $1.0 \mathrm{~cm}$. Bud inherent in the axils of leaves assimilating monocarpic spears deployed in elongated vegetative shoots enrichment with 2 - 3 pairs of leaves that are 5.0 - $10 \mathrm{~mm}$ in length. Monocarpic spear ends frontal cymose thyrsus of inflorescence, consisting of two oppositely arranged dichasium holding $1-3$ flowers. The main root is $40-60$ $\mathrm{cm}$ in length, branching to IV order. This ontogenetic state of the plants are 3 - 4 years.

In the mature state of generative (g2) the individual reaches the maximum size. The bush is $24-26$ monocyclic elongated generative and 2 - 4 annual elongated vegetative shoots located on the compound 4 - 6 (sympodial) skeletal axes formed 2 - 3 annual growth, which can reach a diameter of $0.5 \mathrm{~cm}$. The formation of new axles derived from dormant buds located at the sites of short metameres first annual growth of skeletal axis of the previous order. This leads to severe overcrowding of the axes in the bush. When the mobility of scree and the considerable thickness of the length of the main axes of stones is 5 - $8 \mathrm{~cm}$, in the absence of these factors- 1.5 - 2 $\mathrm{cm}$. Skeletal spine branches. Shoots formed branching from the buds and of the first elongate truncated metameres, resulting in the formation zone of bushing consisting of shoots several orders of magnitude. The length of the generative shoots reaches $12-15 \mathrm{~cm}$, length assimilating leaves $2.0-5.0 \mathrm{~cm}$, width of $1.0-3.0 \mathrm{~cm}$. Generative shoots orthotropic branches in the aerial part, forming paracladium and elongated vegetative shoots enrichment. Usually spear deployed paracladium 2 and 1 - 3 vegetative shoots. The length of the main inflorescence 4.0 - $12 \mathrm{~cm}$ number opposite dichasium carrying 3 flowers, growing to 6 - 8 on paracladium formed to 3 dichasium reduced. As a result, the complete withering away of the old main axes in this state can be partially particulation, exciting and the main root. The main root of the mature generative state can reach up to $100-150 \mathrm{~cm}$ in length and $3 \mathrm{~cm}$ in diameter in the basal part. Duration of mature generative state is 6 - 8 .

For plants, the old generative (g3) condition characterized by complete particulation bush, and the formation of compact clones from branching particul. In addition to living in clone long dead particul saved. Branching particul is consists of $2-3$ generative shoots elongate $10-20 \mathrm{~cm}$ tall. Leaves of generative shoot is $1.5-2.0 \mathrm{~cm}$ long and $0.5-1.0 \mathrm{~cm}$ wide. The length of the main inflorescence is $10-12 \mathrm{~cm}$ paracladium number on the main axis 1 , or completely absent. The plants are located in the ontogenetic state not more than 3 years. Split part of the main root is covered with bark and functioning normally.

With the loss of the ability to form reproductive organs, individuals become the subsenile (ss) state. Subsenile plant presented a clone consisting of the living and the dead particul or separate branching particul having 2 - 3 elongated vegetative shoots a maximum height of $2.0-4.0 \mathrm{~cm}$ with $4-6$ pairs of juvenile green leaves on long stalks of type 1.0 - $1.5 \mathrm{~cm}$ long. Resuming shoots comes from dormant buds located on the perennial parts of the axes. Divided root begins to wither away with the apical end.

Individual's senile age (s) submitted 1-2 elongated shoots from dormant buds unfolded, preserved in the living areas of the axes, and heavily damaged parts of the main root. Spear bears 2 - 6 pairs of leaves juvenile type. Post generative period lasts for 2 - 3 years (Figure 3).

Thus, in terms of individuals duration ontogeny L. proskorjakovii last 22 - 23 years in Nuratau.

Ontogenetic structure of coenopopulation of L. proskorjakovii has not been previously studied. But ontogenetic structure of other species from genus Lagochilus Bunge as L. gypsaceus [22], and some species of the genus Tulipa [23] were studied. Our investigations have revealed that the studied coenopopulations are normal, but not complete (Figure 4). Coenopopulaton of self-maintenance is solely due to the seed of renewal.

The $1^{\text {st }} \mathrm{CP}$ has a generative and old individuals, and at the second coenopopulation regenerative and post generative individuals are absent. At the $3^{\text {rd }}$ and $4{ }^{\text {th }} \mathrm{CP}$ old plants were not recorded; in the $3^{\text {rd }} \mathrm{CP}$ young group is represented by small proportion of juvenile and immature individuals $(10 \%)$. A small proportion $\left(3^{\text {rd }} \mathrm{CP}\right)$, or the absence of the young fraction $\left(1^{\text {st }}, 2^{\text {nd }}\right.$ and $\left.3^{\text {rd }} \mathrm{CP}\right)$ in populations is probably due to the ecology of the species. 


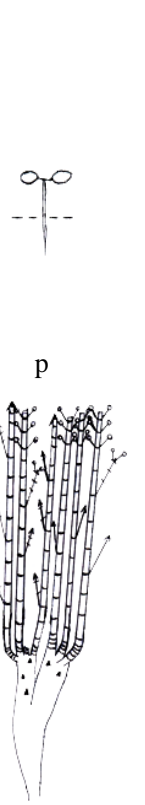

g2

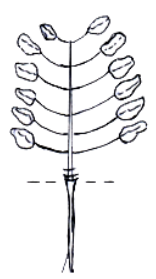

j

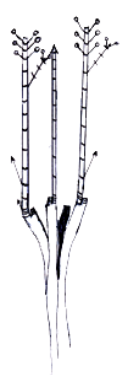

g3

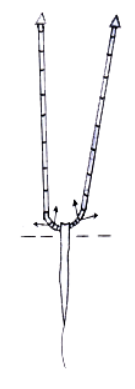

$\mathrm{v}$

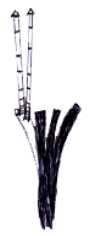

SS
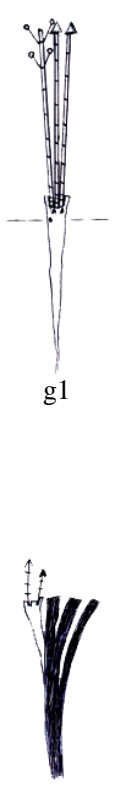

g1

$\mathrm{S}$

Figure 3. Symbols of the developmental state: $\mathrm{j}$ - juvenile, im—immature, v-virginal, g1young generative, g2 — middle-generative, g3 — old generative, ss—subsenile, s—senile.
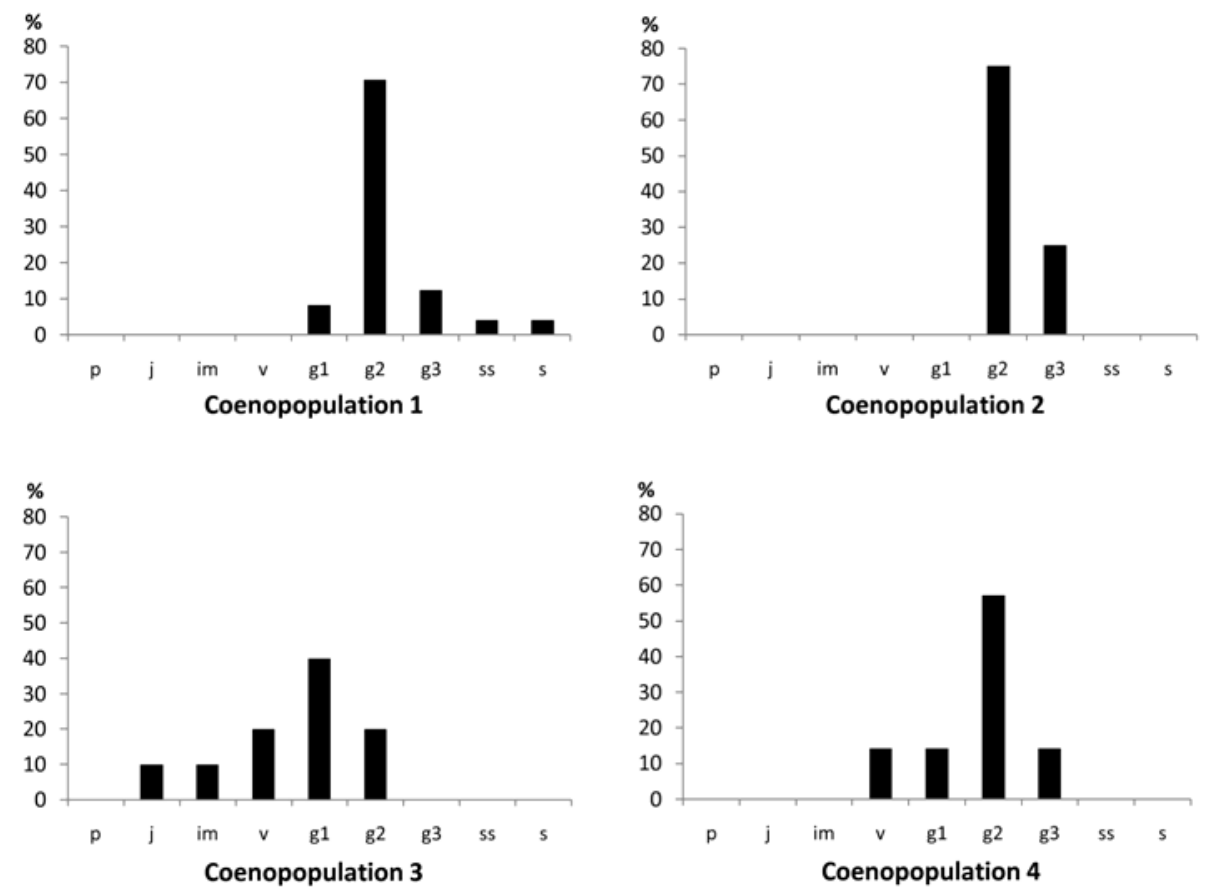

Figure 4. Developmental population spectra of L. proskorjakovii. Note: $\mathrm{x}$-developmental state, $\mathrm{y}$-distribution of individuals on developmental states, $\%$.

As stenobiont in the vast majority of cases, L. proskorjakovii grows on talus deposits. These environmental conditions adversely affect the retention of seeds along the parent birds and their germination. The autumn-winterspring rainfall easily washes away seeds from debris and thus prevents wide distribution of the plant. Besides constant stone moving is often destroys immature juveniles in its path. 
The percentage of the left part of the spectrum in the $3^{\text {rd }} \mathrm{CP}$ is of $40 \%$, in the $4^{\text {th }} \mathrm{CP}$ not more than $15 \%$, while in other coenopopulations it is equal to zero. In most cases, specific developmental spectrum of coenopopulations $\left(1^{\text {st }}, 2^{\text {nd }}\right.$ and $\left.4^{\text {th }} \mathrm{CP}\right)$ coincides with the characteristic individuals.

In all developmental spectrum unimodality of coenopopulations were observed: the $1^{\text {st }}, 2^{\text {nd }}$ and $4^{\text {th }} \mathrm{CP}$ are centered; in the $3^{\text {rd }} \mathrm{CP}$-left-handed. A peak in the spectra of the $1^{\text {st }}, 2^{\text {nd }}$ and $4^{\text {th }} \mathrm{CP}$ have a group of middlegenerative plant (71\%, 75\% and 58\% respectively); at the $3^{\text {rd }} \mathrm{CP}$ generative-on young plants (40\%) (Figure 4). Accumulation of middle-generative plants in populations is due on the one hand with a long development of the developmental group of individuals, and on the other the least of their elimination. The maximum value of the young generative group in the $3^{\text {rd }} \mathrm{CP}(40 \%)$ is due to the successive nature of coenopopulation. Recently entered into this community, individuals of $L$. proskorjakovii not yet finished their ontogeny. This is evidenced by the low value of middle-generative and no older generative individuals.

The average density of individuals in populations ranged from 0.4 to $1.2 \mathrm{ind} / \mathrm{m}^{2}$ (Table 2). According to the classification of Zhyvotovskiy [19] $1^{\text {st }}, 2^{\text {nd }}$ and $4^{\text {th }} \mathrm{CP}$ are mature and $3^{\text {rd }} \mathrm{CP}$ is maturing (Figure 5).

\section{Conclusions}

North-western mountain range of the Pamir-Alai-Nuratau mountains are one of the most peculiar and interesting regions of Central Asia, in the sense that it is located in the connection of two major sub-compartments of botanical-geographical zoning on the one hand with Central Asian mountainous and on the other hand the Turan floristic provinces. This explains the originality of their physical and geographic appearance and biodiversity in general. Floristical diversity of Nuratau is low (about 1285 species of vascular plants) due to arid conditions and lack of high mountains. L. proskorjakovii, grows on talus deposits slopes is one of the narrow local endemic mountain Nuratau. It usually occurs in rarefied herbage in the composition and formation of Amygdalus bucharica + Perovskia scrophulariifolia, where the projective cover is less than $20 \%$.

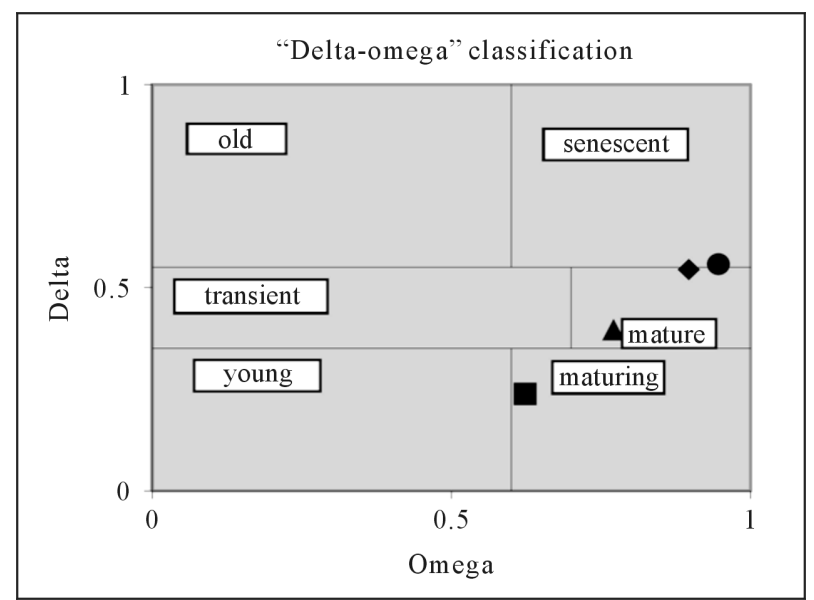

Figure 5. Type coenopopulations of L. proskorjakovii. The $1^{\text {st }} \mathrm{CP}$ mature $(\bullet)$, the $2^{\text {nd }} \mathrm{CP}$ mature $(\bullet)$, the $3^{\text {rd }} \mathrm{CP}$ maturing $(\boldsymbol{\nabla})$, the $4^{\text {th }} \mathrm{CP}$ mature $(\boldsymbol{\Delta})$.

Table 2. Demographic characteristics coenopopulations of L. proskorjakovii.

\begin{tabular}{ccccc}
\hline № CP & $\Delta$ & $\omega$ & $\begin{array}{c}\text { The average density } \\
\text { of individuals } / \mathrm{m}^{2}\end{array}$ & Type CP \\
\hline 1 & 0.54 & 0.89 & 1.2 & Mature \\
2 & 0.55 & 0.94 & 0.4 & Mature \\
3 & 0.23 & 0.62 & 0.5 & Maturing \\
4 & 0.39 & 0.77 & 0.8 & Mature \\
\hline
\end{tabular}


In natural conditions, growth of L. proskorjakovii passes all stages of ontogeny and its duration is at least 23 years. Studied coenopopulations are normal, but are not complete. Coenopopulation of self-maintenance is carried out by the seed renewal. Based on the features of the biology of the species: low germination, rapid transition to flower and slower development of individuals in a generative mature state of coenopopulation spectrum characteristic of this type will be centered type, with a peak in the middle-generative individuals. In most cases, specific developmental spectrum of coenopopulation $\left(1^{\text {st }}, 2^{\text {nd }}\right.$ and $\left.4^{\text {th }} \mathrm{CP}\right)$ coincides with the characteristic individuals. Studied populations from coenotic point of view are characterized by the absence or the low proportion of young fraction due to the ecology of the species. Mobility large rocky slopes lead to the elimination of fragile young individuals. The maximum value of the young generative group in the $3^{\text {rd }} \mathrm{CP}(40 \%)$ is due to the successive nature of coenopopulation. Recently, appeared individuals of $L$. proskorjakovii in the plant community have not yet finished their ontogeny. According to the classification of "delta-omega", the vast majority of coenopopulation $\left(1^{\text {st }}, 2^{\text {nd }}\right.$ and $\left.4^{\text {th }} \mathrm{CP}\right)$ are at the maturing stage, indicating the positive state of coenopopulation demography.

\section{Acknowledgements}

Authors are grateful for Prof. V.A. Cheryomushkina and her laboratory team at Central Siberian Botanical Garden, Siberian Branch Russian Academy of Sciences for their support and assistance to perform description of ontogeny of the studied plant.

\section{References}

[1] Beshko, N.Yu. (2014) Western Tyanshan and Elements of Karatau in the Flora of Nuratau Mountains, Tashkent. 1618.

[2] Beshko, N.Yu. and Azimova, D.E. (2013) New Floristic Findings on the North-West Pamir-Alay (Uzbekistan). Turczaninowia, 16, 197-203.

[3] Vvedenskyi, A.I. (1961) Family. Lamiaceae, Flora of Uzbekistan, Vol. 5, Tashkent Publishing Academy Sciences of Republic of Uzbekistan, 364-373.

[4] (1987) Determiner of Plants of Middle Asia. Critical Conspectus of Flora. Scientific Supervisor Vvedensky A.I. Tashkent. Fan, 9, 119-133.

[5] Pratov, U.P., Kholmatov, H.Kh. and Makhsumov, M.M. (2006) Natural Medicaments. Tashkent, 208 p.

[6] (2009) Red Book of Uzbekistan. Plants and Fungi. Chinor Publishing House, Tashkent, Vol. 1, 356 p.

[7] Beshko, N.Yu. (1997) Rare and Endemic Species of Flora of Nurata Natural Reserve. Transactions of Natural Reserves of Uzbekistan, Mehnat. Tashkent, 2, 18-24.

[8] Akhmedov, A.Q. (2013) Morphobiometrical Values of Different Coenopopulations of Lagochilus vvedenskyi in Kyzylkum Desert. Proceedings of Desert Technology XI International Conference, Texas, 19-22 November 2013, 58-59.

[9] Shomurodov, H.F., Akhmedov, A. and Saribaeva, Sh.U. (2014) Distribution and the Current State of Lagochilus acutilobus (Lamiaceae) in Connection with the Oil and Gas Sector Development in Uzbekistan. Ecological Questions, 19, 45-49. http://dx.doi.org/10.12775/EQ.2014.004

[10] Ikramov, M.I. (1976) Genus of Lagochilus of Middle Asia. Fan. UzSSR, Tashkent, 106-107.

[11] Mirkin, B.M., Naumova, L.G. and Solomeshch, A.I. (2000) The Modern Science of Vegetation. Logos, Moscow, 4951.

[12] Rabotnov, T.A. (1950) Life Cycles of Perennial Grass Plants in Meadow Populations. Transactions of Institute of Botany of Academy of Sciences of USSR, Geobotany, Moscow, Leningrad, 176 p.

[13] Uranov, A.A. (1975) Age Spectrum of Phytocoeno Population as a Function of Time and Energy Wave Processes. Scientific Lectures of Higher Schools, Biological Sciences, No. 2, 7-34.

[14] Smirnova, O.V., Zaugolnova, L.B. and Ermakova, I.M. (1976) Coenopopulations of Plants (Basic Concepts and Structure). Nauka, Moscow, 216 p.

[15] Rachkovskaya, E.I. (1957) On the Biology of Desert Semi Shrubs. Transactions of BIN USSR. Ser. III: Geobotany, Vol. 11, Moscow, 5-87.

[16] Zhukova, L.A. (1995) Population Life of Meadow Plants. Yoshкоr-Ola, 98-106.

[17] Zaugolnova, L.B. (1994) The Structure of the Populations of Seed Plants and Monitoring. Resume of Dissertation of Doctor of Biological Sciences, St. Petersburg, 70 p. 
[18] Uranov, A.A. and Smirnova, O.V. (1969) Classification and Main Features of Development of Populations of Perennial Plants. Bulletin of Moscow Society of Naturalists (Department of Biology), 2, 119-134.

[19] Zhivotovsky, L.A. (2001) Ontogenetic States, Effective Density and Classification of Plant Populations. Russian Journal of Ecology, 32, 1-5.

[20] Odum, U. (1986) Ecology. Vol. 2, Mir, Moscow, 209 p.

[21] Czerepanov, S.K. (1995) Vascular Plants of Russia and Adjacent States (the Former USSR). Cambridge University Press, New York, $152 \mathrm{p}$.

[22] Akhmedov, A.Q., Cheryomushkina, V.A. and Shomurodov, H.F. (2015) Ontogenesis and Ontogenetic Structure of Lagochilus gypsaceus Vved (Lamiaceae) Coenopopulations in Kyzylkum (Uzbekistan). Rastitel'nyj Mir Aziatskoj Rossii (Plant Life of Asian Russia), No. 2(8), 32-38.

[23] Abduraimov, O.S. and Shomurodov, H.F. (2015) The Ontogenesis and Ontogenetic Structure of Tulipa mecheliana Th. Hoog (Liliaceae) Coenotic Populations in Uzbekistan. Journal of Novel Applied Sciences, 4, 1089-1096. 